\title{
ASSESSMENT OF NEWBORN SCREENING IN THE PUBLIC HEALTH SYSTEM OF A MUNICIPALITY IN NORTHERN RIO GRANDE DO SUL
}

\author{
Tássia Tonon ${ }^{1,2}$, Elisa Sisti ${ }^{3}$, Tatiéle Nalin ${ }^{1,2}$, \\ Ida Vanessa Doederlein Schwartz 2,4
}

\begin{abstract}
Introduction: Newborn screening allows the screening of diseases that are still in the asymptomatic period and whose early diagnosis and treatment are associated with reduced infant morbidity and mortality. The aim of this study was to evaluate the public National Newborn Screening Program in the municipality of Carazinho, state of Rio Grande do Sul (RS), Brazil.
\end{abstract}

Methods: This was a population-based, retrospective, descriptive study. We collected and transcribed data from a database of the Carazinho municipal laboratory, which is affiliated with the referral center for newborn screening in RS. The records of all individuals undergoing newborn screening from 2005 to 2010 were reviewed, and information was collected on the program coverage, time elapsed between birth and screening (first collection), and test results.

Results: The program had a coverage of $75.5 \%$. One suspected case of phenylketonuria, three suspected cases of congenital hypothyroidism and no suspected cases of hemoglobinopathy were identified. In addition, there were 18 positive results for hemoglobin S heterozygosity, five for hemoglobin D heterozygosity, two for hemoglobin $\mathrm{C}$ heterozygosity, and one for a rare variant hemoglobin. When analyzing the newborn's age at the time of blood collection, it was observed that $63.1 \%$ were within the recommended age range.

Conclusions: Our findings suggest the need for optimization of public newborn screening in the evaluated municipality. The strategies to be adopted should include education of the population and especially of managers and health professionals about the importance of newborn screening.

Keywords: Newborn screening; public health; mass screening

Newborn screening, also known as the heel-prick test because blood is collected from the newborn's heel, includes a series of laboratory tests that aim to identify certain genetic diseases in the asymptomatic stage. The first blood sample should preferably be collected between the third and fifth day of life ${ }^{1}$. This is an important strategy to reduce infant morbidity and mortality through early detection of treatable diseases that may lead to severe clinical presentations $\mathbf{s}^{2,3}$. Therefore, the adoption of preventive actions, as early diagnosis and treatment, can change the natural history of diseases detected by newborn screening ${ }^{4}$. The selection of diseases for inclusion in a newborn screening program is mainly based on three criteria: a) disease detection should be feasible in the pre-symptomatic period; $b$ ) the disease should be treatable; and c) there should be the possibility of starting treatment at early disease stages ${ }^{5}$.

Over the past two decades, the introduction of tandem mass spectrometry (MS/MS) has substantially expanded the number of disorders that can be detected in dried blood spot on filter paper. This test allows the simultaneous detection of more than 30 diseases, including organic acidemias and disorders of fatty acid metabolism ${ }^{5}$. Congenital hypothyroidism $(\mathrm{CH})$ is the most widely screened disease in newborn screening programs worldwide ${ }^{6}$.
Clin Biomed Res. 2018;38(2):123-127

1 Programa de Pós Graduação em Medicina: Ciências Médicas, Universidade Federal do Rio Grande do Sul (UFRGS). Porto Alegre, RS, Brasil.

2 Serviço de Genética Médica, Hospital de Clínicas de Porto Alegre (HCPA). Porto Alegre, RS, Brasil.

3 Departamento de Biomedicina, Universidade Luterana do Brasil (ULBRA). Carazinho, RS, Brasil.

4 Departamento de Genética, Universidade Federal do Rio Grande do Sul (UFRGS). Porto Alegre, RS, Brasil.

Corresponding author:

Tássia Tonon

tassitonon@gmail.com

Programa de Pós Graduação

em Medicina: Ciências Médicas

Universidade Federal do Rio Grande do Sul (UFRGS)

Rua Ramiro Barcelos, 2400

90035-003, Porto Alegre, RS, Brasil. 
In Brazil, a newborn screening program was initiated in the city of São Paulo in the 1970s by the pediatrician Benjamim Schmidt, with screening tests for phenylketonuria in the Association of Parents and Friends of Special Need Individuals (Associação de Pais e Amigos dos Excepcionais, APAE). In 2001, the Brazilian Ministry of Health implemented the National Newborn Screening Program (Programa Nacional de Triagem Neonatal, PNTN) through Regulation No. 822 of June 06,2001 . This regulation established a series of tests for early disease screening, diagnostic confirmation, treatment, follow-up, and database recording, with an intended coverage of $100 \%$ live births. The availability of tests was defined for each Brazilian state based on the preexisting coverage and infrastructure of health care services. The program was divided into three screening phases, as follows: Phase I - phenylketonuria and $\mathrm{CH}$; Phase II phenylketonuria, $\mathrm{CH}$, and hemoglobinopathies; and Phase III - phenylketonuria, $\mathrm{CH}$, hemoglobinopathies, and cystic fibrosis ${ }^{7}$.

Later, Regulation No. 2,829 of December 14, 2012, included newborn screening for congenital adrenal hyperplasia and biotinidase deficiency within the scope of the program, encompassing all states in a single category ${ }^{8}$. Currently, there are 30 referral centers for newborn screening (Serviços de Referência em Triagem Neonatal, SRTN) in the 27 Brazilian federative units, which serve 17,854 collection stations ${ }^{9}$. Expanded screening, which enables the detection of up to 30 diseases, is provided by the public health system only in the Federal District and is available as a pilot program in the state of Minas Gerais ${ }^{6}$.

Newborn screening in the state of Rio Grande do Sul (RS) began in the late 1980s as isolated initiatives in public hospital laboratories. It was only in 1994 that the state government began to offer screening tests in partnership with Universidade Federal do Rio Grande do Sul (UFRGS) and UFRGS School of Pharmacy. Currently, the referral institution for newborn screening in the state of RS is Hospital Materno Infantil Presidente Vargas, where the SRTN operates. Like most centers in other states, this SRTN is equipped with its own laboratory, which performs more than 60,000 laboratory tests per month. In 2015, the SRTN served 1,307 collection stations throughout the 497 municipalities that provide newborn screening as a public health service in the state ${ }^{1}$.

First introduced in the United States in 1963, newborn screening is celebrating its 55th anniversary in 2018 , coinciding with the 17 th anniversary of the PNTN in Brazil. Therefore, an update on results is warranted to reflect the current state of newborn screening practice at the municipal level. The present study aimed to describe and evaluate newborn screening provided as a public health service in a municipality of the state of RS from 2005 to 2010.

\section{METHODS}

This population-based, observational, descriptive study with retrospective data collection was conducted in Carazinho, a municipality located in central-northern RS. In 2010, the population was 59,317 inhabitants ${ }^{10}$, and the municipality was served by the 6th Regional Health District of Rio Grande do Sul.

The study was approved and data collection was authorized by the Municipal Health Department in Carazinho. Data were collected from the database of the Carazinho municipal laboratory, which contains all the results of newborn screening tests performed by the SRTN in the municipality.

The records of all individuals undergoing newborn screening from 2005 to 2010 were reviewed for information on the time elapsed between birth and screening and on the results of screening tests. During the study period, RS was in the Phase II of PNTN, i.e., screening for phenylketonuria, $\mathrm{CH}$, and hemoglobinopathies.

The coverage of the screening program in Carazinho was determined based on data from the IT Department of the Brazilian Unified Health System (DATASUS), considering all live births occurring in the municipality from 2005 to 2010 . Coverage was calculated as the number of tests performed multiplied by 100 and divided by the number of live births.

For age at collection of biological samples, we considered the period recommended before the Regulation No. 2,829 of 2012 became effective, i.e., blood collection up to the seventh day of life. After 2012, the ideal collection period was shortened to the fifth day of life, and delayed collection was defined as that performed after the sixth day of life.

Of note, regarding the screened diseases, we describe the results of screening tests, and not of confirmatory tests, as the latter were not made available to the researchers.

\section{RESULTS}

From 2005 to $2010,4,647$ children were born in Carazinho. Of these, 3,417 (75.5\%) were screened for phenylketonuria and $\mathrm{CH}$ in the public health system. However, 3,410 (73.4\%) children were screened for hemoglobinopathies because they had undergone transfusion procedures before collection. The results of the seven children screened for hemoglobinopathies 30 days after transfusion were not available at the time of data collection.

One suspected case of phenylketonuria and three suspected cases of $\mathrm{CH}$ were identified by laboratory analysis. There was no suspected case of hemoglobinopathy. In 18 cases, the results were positive for hemoglobin $\mathrm{S}$ heterozygosity, in five cases 
Table 1: Newborn's age at blood collection for newborn screening (2005-2010).

\begin{tabular}{ccc}
\hline Newborn's age & $\%$ & $\mathbf{n}$ \\
\hline$<7$ days of life & 2.157 \\
$7-30$ days of life* & 63.1 & 1.192 \\
$>30$ days of life* & 34.9 & 68 \\
\hline
\end{tabular}

*Collection period recommended by the Brazilian Ministry of Health before Regulation no. 2.829 of 2012.

for hemoglobin D heterozygosity, in two cases for hemoglobin $\mathrm{C}$ heterozygosity, and in one case for a rare variant hemoglobin.

Table 1 shows the newborn's age at the time of blood collection stratified according to the collection period recommended by the Brazilian Ministry of Health.

\section{DISCUSSION}

Newborn screening, which was consolidated in Brazil through the PNTN, aims to improve the quality of life of individuals affected by several diseases through early diagnosis. The introduction of the PNTN has been associated with a marked reduction in infant mortality over the years ${ }^{4}$. However, the proper implementation of this program still faces difficulties, such as the lack of financial resources, mobilization of the target audience and awareness of health managers, and inappropriate time of collection or transportation. This becomes evident from the wide variation and discrepancy across Brazilian states in the results reported in the "Situation Diagnosis of the PNTN", a survey conducted together with the Brazilian Ministry of Health in $2013^{11}$.

Estimating the coverage of newborn screening is extremely important because it enables to analyze the percentage of children who were not screened, thereby allowing a partial analysis of the situation of the program under study. After the PNTN was established in 2001, there was an increase in the coverage of newborn screening in Brazil, reaching $80 \%$ in 2005 , although it was heterogeneously distributed among states $^{2}$. Currently, all Brazilian states and the Federal District have SRTNs and collection stations, the latter being usually located in primary health care units. In 2013, the exact number of tests performed and patients receiving follow-up was unknown by state managers and by the Brazilian Ministry of Health ${ }^{11}$. In 2016, according to the Brazilian Ministry of Health, the coverage of public newborn screening was $83.6 \%$ in Brazil $^{12}$. In 2015, the coverage reached $83 \%$ in $\mathrm{RS}^{1,2}$. In the municipality of Carazinho, according to data from a master's degree thesis, the coverage was $72.2 \%$ in $2006^{13}$.

A newborn screening program is successful when there is government priority and funding, population education and acceptance, engagement of health care professionals, and government participation in the implementation of the program ${ }^{11}$. The municipality under study did not achieve the ideal coverage of public screening recommended by the Brazilian Ministry of Health. However, it is important to point out that coverage rates may have been underestimated, since tests may have been performed in private health facilities and, therefore, were not available for analysis.

The low coverage of newborn screening in Brazil is justified by various reasons, the most important of which are the tests performed in the private health system, poor dissemination of the PNTN, and cultural traits that neglect the importance of newborn screening. The extent of this coverage is known to be directly influenced by cultural and socioeconomic factors, as demonstrated in more developed countries like Spain, France, Italy, Austria, Russia, New Zealand, Scotland, and Australia, where coverage is close to or reaches $100 \%{ }^{2}$.

According to some authors, it is essential to collect blood samples for newborn screening before hospital discharge in order to achieve a satisfactory coverage and to meet the ideal collection period ${ }^{14}$. However, it would be necessary, in the case of phenylketonuria, for example, to reduce cutoff points for normal and abnormal phenylalanine levels in order to identify children who had low protein intake through breastfeeding in their first hours of life. The unfavorable aspect of this strategy is that it would increase the number of false positive cases, which may increase costs because of the need for additional tests, also increasing the family's anxiety. Also worthy of note is that blood collection through the Brazilian Unified Health System (Sistema Único de Saúde) and the PNTN should be performed in an outpatient setting, except in special cases such as preterm infants and those with prolonged stay in the neonatal intensive care unit.

The PNTN has some guidelines and standards for the period of blood sample collection for newborn screening. The ideal collection period was up to the seventh day of life before Regulation No. 2,829 of 2012 , which was shortened to the fifth day of life after the publication of this regulation. In 2015, 2.5 million newborns were screened in the PNTN. Of these, 
only $53 \%$ were tested before the fifth day of life ${ }^{11}$. In Carazinho, most children were screened within the ideal period recommended by the guidelines in effect at the time of the study. It is worth noting that this period may vary among different countries, since it depends of the sensitivity of diagnostic technologies ${ }^{4}$ and needs inherent in the diseases included within the scope of the screening program.

Regarding the incidence of the screened diseases, the reported numbers vary worldwide. For example, the worldwide incidence of phenylketonuria, a rare genetic disease in which a metabolic defect leads to the accumulation of blood phenylalanine, is estimated at 1 in approximately 10,000 newborns ${ }^{5}$, and varies among countries and regions because of differences in rates of consanguinity ${ }^{15}$. In Brazil, the incidence of phenylketonuria was estimated at 1:15,839 newborns in 2001 and 1:24,780 newborns in $2002^{16}$. In 1996, Jardim et al. estimated that 1 in every 12,500 live births had phenylketonuria in $\mathrm{RS}^{17}$. In this state, screening (first sample) is performed through quantitative dosing of blood phenylalanine using filter paper, and abnormal results are confirmed by more specific tests (second sample) performed using serum, whole blood or urine samples ${ }^{1}$.

Similar findings have been reported for $\mathrm{CH}$, the most common congenital endocrine disorder, whose incidence has been found to vary among ethnic groups, with lower prevalence rates in African Americans than in Hispanics. Moreover, women are known to be more affected than men (at a 2:1 ratio), as well as children with Down syndrome. $\mathrm{CH}$ is caused by failure of the thyroid gland to produce adequate amounts of thyroid hormones, resulting in a generalized reduction in metabolic processes ${ }^{4}$. Currently, $\mathrm{CH}$ has a worldwide incidence of 1 in approximately 3,500 live births ${ }^{4}$. A similar incidence has been observed in Brazil, where the estimated rates range from $1: 2,595$ to $1: 4,795$ live births ${ }^{1,18}$. In the
PNTN, $\mathrm{CH}$ is screened by dosing thyroid-stimulating hormone (TSH) with filter paper. $\mathrm{CH}$ is confirmed if serum TSH levels are above $20 \mathrm{mUI} / \mathrm{L}$. Reduced levels of total T4, free T3 and free T4 confirm the diagnosis of primary defect in the thyroid gland ${ }^{1}$.

As for hemoglobinopathies, these are the most prevalent genetic diseases in humans, and the most frequent and clinically significant variants are those affecting hemoglobin S and $\mathrm{C}$. This disease is characterized by a structural defect in the beta chain of hemoglobin leading to the formation of sickle-shaped red blood cells. Data from the literature show that sickle cell anemia is 10 to 30 times more common than phenylketonuria, especially in regions where the population is of mixed race, like the Brazilian state of Bahia, where the incidence of sickle cell anemia is $1: 650$ live births ${ }^{19,20}$.

The heel-prick test is economically feasible for the government, leading to a reduction in the number of disabled individuals and reducing expenditures on benefits to people with disabilities ${ }^{21}$. This study highlights the complexity of the PNTN, resulting from the vastness of the Brazilian territory and cultural diversity in the country, with an urgent need to improve the program. In conclusion, future strategies should focus on improving indicators and enabling the proper development of the program, including the following aspects: population awareness; education of managers from the three government spheres and of health professionals about the importance of the program; and consequent enhancement of actions and results for the benefit of the entire Brazilian population.

This study was performed at Universidade Luterana do Brasil (Carazinho, southern Brazil).

\section{Conflicts of Interest}

The authors declare no conflicts of interest.

\section{REFERENCES}

1. Kopacek C. Evolução e funcionamento do Programa Nacional de Triagem Neonatal no Rio Grande do Sul de 2001 a 2015. Boletim Científico de Pediatria. 2015;4:70-4.

2. Botler J, Camacho LAB, Cruz MM, George P. Triagem neonatal: o desafio de uma cobertura universal e efetiva. Ciênc. Saúde Coletiva. 2010;15(2):493-508. http://dx.doi.org/10.1590/S141381232010000200026
3. Pitt JJ. Newborn screening. Clin Biochem Rev. 2010;31(2):57-68. PMid:20498829.

4. Brasil. Ministério da Saúde. Secretaria de Atenção a Saúde. Departamento de Atenção Especializada e Temática. Triagem Neonatal biológica: manual técnico. Brasília: Ministério da Saúde; 2016.

5. Burgard P, Luo X, Levy HL, Hoffmann GF. Phenylketonuria. In: Sarafoglou K, Hoffmann GF, Roth KS. Pediatric
Endocrinology and Inborn Errors of Metabolism. 2nd ed. New York: McGraw-Hill Education; 2017. p. 251256.

6. Therrell BL, Padilla CD, Loeber JG, Kneisser I, Saadallah A, Borrajo GJ, et al. Current status of newborn screening worldwide. Semin Perinatol. 2015;39(3):171-87. http://dx.doi. org/10.1053/j.semperi.2015.03.002. PMid:25979780. 
7. Brasil. Ministério da Saúde Secretaria de Assistência à Saúde. Coordenação-Geral de Atenção Especializada. Manual de normas técnicas e rotinas operacionais do programa nacional de triagem neonatal. Brasília: Ministério da Saúde; 2002.

8. Brasil. Ministério da Saúde. Portaria n. 2.829, de dezembro de 2012. Inclui a Fase IV no Programa Nacional de Triagem Neonatal (PNTN), instituído pela Portaria $n^{\circ} 822 / \mathrm{GM} / \mathrm{MS}$, de 6 de junho de 2001. Diário Oficial da União. Disponível em: http://bvsms. saude.gov.br/bvs/saudelegis/gm/2012/ prt2829_14_12_2012.html

9. Brasil. Ministério da Saúde. Programa Nacional de Triagem Neonatal. Nota informativa. 2012. [cited 2013 Oct 11]. Available from: http://portalarquivos. saude.gov.br/images/pdf/2015/ julho/13/2.\%20a\%20-\%20NI_PNTN_ Nov-2012-CIT_SAS.pdf

10. Instituto Brasileiro de Geografia e Estatística - IBGE. População no último censo (2010).. Brasília: IBGE. [cited 2013 Oct 11]. Available from: https://cidades.ibge.gov.br/brasil/rs/ carazinho.

11. Brasil. Ministério da Saúde. Secretaria de Atenção à Saúde. Universidade Federal de Minas Gerais. Faculdade de Medicina da Universidade Federal de Minas Gerais. Núcleo de Ações e Pesquisa em Apoio Diagnóstico. Diagnóstico situacional do Programa
Nacional de Triagem Neonatal nos estados brasileiros: relatório técnico. Belo Horizonte: NUPAD; 2013.

12. Brasil. Ministério da Saúde. Recémnascidos devem fazer Teste do Pezinho até o $5^{\circ}$ dia de vida [Internet]. 2016 Out 12 [cited 2017 July 11]. Available from: http://www.brasil.gov. br/saude/2016/10/recem-nascidosdevem-fazer-o-teste-do-pezinho-ateo-5-dia-de-vida

13. Goldbeck AS. A triagem neonatal (Teste do Pezinho) na rede de atenção básica em saúde do Rio Grande do Sul: representações sociais e qualificação do processo comunicacional [monografia]. Porto Alegre: Escola de Administração, Universidade Federal do Rio Grande do Sul; 2006.

14. Silva MBGM, Lacerda MR. Teste do Pezinho: Por que coletar na alta hospitalar? Revista Eletrônica de Enfermagem. 2003;5(2):60-64.

15. Jahja R, van Spronsen FJ, Sonneville LMJ, van der Meere JJ, Bosch AM, Hollak CEM, et al. Long-term follow up of cognition and mental health in adult Phenylketonuria: a PKU-COBESO study. Beha Genet. 2017;47(5):486497. http://dx.doi.org/10.1007/s10519017-9863-1.

16. Carvalho TM. Resultados do levantamento epidemiológico da Sociedade Brasileira de Triagem Neonatal (SBTN). Rev Med Minas Gerais. 2003;13:9-35.
17. Jardim LB, Palma-Dias R, Silva LC, Ashton-Prolla P, Giugliani R. Maternal hyperphenylalaninemia as a cause of microcephaly and mental retardation. Acta Paediatr. 1996;85(8):943-6. http://dx.doi. org/10.1111/j.1651-2227.1996. tb14191.x. PMid:8863876.

18. Maciel LMZ, Kimura ET, Nogueira CR, Mazeto GM, Magalhães PKR, Nascimento ML, et al. Hipotireoidismo congênito: recomendações do Departamento de Tireoide da Sociedade Brasileira de Endocrinologia e Metabologia. Arq Bras Endocrinol Metabol. 2013;57(3):184-92. http://dx.doi.org/10.1590/S000427302013000300004.

19. Sommer CK, Goldbeck AS, Wagner SC, Castro SM. Triagem Neonatal para hemoglobinopatias: experiência de um ano na rede de saúde pública do Rio Grande do Sul, Brasil. Cad Saude Publica. 2006;22(8):170914. http://dx.doi.org/10.1590/ S0102-311X2006000800019. PMid:16832542.

20. Brasil. Ministério da Saúde. Ministério da Saúde, Secretaria de Atenção à Saúde, Departamento de Atenção Especializada. Doença falciforme: condutas básicas para tratamento. Brasília: Ministério da Saúde; 2012. (Série B. Textos Básicos de Saúde).

21. Freitas MNM. A Importância do Teste do Pezinho. Rev Saberes Rolim de Moura. 2015;3:2-13. 